\title{
Cu- and Ni-Doping Effect on Structure and Magnetic Properties of Fe-Doped ZnO Nanoparticles
}

\author{
Jefferson A. Wibowo, Nadia F. Djaja, Rosari Saleh* \\ Departemen Fisika, FMIPA-Universitas Indonesia, Depok, Indonesia \\ Email: ${ }^{*}$ rosari.saleh@ui.ac.id, ${ }^{*}$ rosari.saleh@gmail.com \\ Received January 7, 2013; revised February 8, 2013; accepted February 18, 2013
}

\begin{abstract}
$\mathrm{Cu}$ - and Ni-codoped FeZnO particles with the wurzite structure were successfully synthesized at low temperature by a co-precipitation method. The samples were characterized using a vibrating sample magnetometer, X-ray diffraction, energy dispersive X-ray spectroscopy, UV-Vis spectrophotometry and electron spin resonance. The results demonstrated that room temperature ferromagnetic order was observed in both samples and the magnetization was higher than that of Fe-doped $\mathrm{ZnO}$. The correlation between the structural and magnetic properties is discussed.
\end{abstract}

Keywords: Codoped ZnO Nanoparticles; Room-Temperature-Ferromagnetic; Co-Precipitation

\section{Introduction}

Dilute magnetic semiconductors (DMSs) in which some of the cations host lattice are replaced by a transition metal ions have attracted considerable attention due to their potential as spin-polarized carrier sources and their potential applications in spintronic devices [1-5]. The main challenge for practical application of DMSs is the attainment of Curie temperature above room temperature [6]. Following the theoretical prediction of room temperature ferromagnetic by Dietl et al. [7], several studies involving magnetic ions doped II-VI semiconductors were performed by different researcher in transition metal doped $\mathrm{ZnO}$. It is known that $\mathrm{ZnO}$ has high solubility for transition metals and superior semiconductor properties [8]. Moreover, $\mathrm{ZnO}$ is a wideband gap semiconductor with a relative large exciton binding energy. Among transition metal, $\mathrm{ZnO}$ doped with $\mathrm{Fe}$ ions without any modification of the structure has been the most considerable interest. Ferromagnetism with Curie temperature higher than room temperature has been observed in Fe-doped [9-12], Co-doped [13-15], Mn-doped [16-18], Ni-doped [19-21], Cu-doped [22] and V-doped [23] ZnO nanoparticles. Meanwhile, several codoped $\mathrm{ZnO}$ have also been reported with the expectation that codoping can lead to remarkable changes in the properties of the materials [24-26]. Presence of two different kind of transition ions simultaneously in a host material produces magnetic property that can be different from the magnetic property due to single transition metal ions. For instance, Han et al. [27] reported that the Curie tem-

${ }^{*}$ Corresponding author. perature of bulk $\mathrm{Zn}_{0.94} \mathrm{Fe}_{0.05} \mathrm{Cu}_{0.01} \mathrm{O}$ was above room temperature and the maximum saturation of magnetization was larger than that of the sample without $\mathrm{Cu}$ [27,28]. Shim et al. [29] also prepared $\mathrm{FeCu}$ co-doped $\mathrm{ZnO}$ sample and reported that the room temperature ferromagnetic in the sample is due to the secondary phase $\mathrm{ZnFe}_{2} \mathrm{O}_{4}[27,29]$.

Despite the considerable amount of data a great deal of controversy remains, especially regarding the fundamental issue of whether the system actually exhibits room temperature ferromagnetic at all; and in the case where it does, whether the effect is intrinsic to the material. Further studies suggested that the inconsistencies in the literature regarding the ferromagnetic ordering of transition metal doped $\mathrm{ZnO}$ indicate that these materials are very sensitive to the fabrication and processing conditions. Therefore, this paper we attempt to study the effect of $\mathrm{Cu}$ - and $\mathrm{Ni}$ co-doping on the weakest ferromagnetic $\mathrm{Fe}$ doped $\mathrm{ZnO}$ ( 1 at $\%$ of $\mathrm{Fe}$ ). The co-precipitation method was chosen for the synthesis of these materials because it is cost effective, requires low temperature processing and offers a higher degree of solubility. The effects of $\mathrm{Cu}$ and $\mathrm{Ni}$ doping on the structural, optical and magnetic properties of nanocrystalline Fe-doped $\mathrm{ZnO}$ particles was investigated using X-ray diffraction (XRD), energy dispersive $\mathrm{X}$-ray (EDX), UV-Vis spectroscopy (UV-Vis), electron spin resonance (ESR) and vibrating sample magnetometer (VSM). It was found that the incorporation of $\mathrm{Cu}$ and $\mathrm{Ni}$ in $\mathrm{Fe}$-doped $\mathrm{ZnO}$ nanoparticles not only enhances ferromagnetic properties to the host materials but also changes lattice constant and the optical properties. 


\section{Experimental}

For the synthesis of $\mathrm{Cu}$ - and Ni-doping of $\mathrm{Fe}$-doped $\mathrm{ZnO}$ nanoparticles in this study the following starting materials were used without further purification: zinc (II) sulfate ( $\mathrm{ZnSO}_{4} \cdot 7 \mathrm{H}_{2} \mathrm{O}, 99 \%$, Merck), iron (II) sulfate $\left(\mathrm{FeSO}_{4} \cdot 7 \mathrm{H}_{2} \mathrm{O}\right.$, $99 \%$, Merck), cooper (II) sulfate $\left(\mathrm{CuSO}_{4} \cdot 5 \mathrm{H}_{2} \mathrm{O}, 99 \%\right.$, Merck) and nickel (II) nitrate $\left(\mathrm{Ni}\left(\mathrm{NO}_{3}\right)_{2} \cdot 6 \mathrm{H}_{2} \mathrm{O}, 99 \%\right.$ Merck). $\mathrm{FeSO}_{4} \cdot 7 \mathrm{H}_{2} \mathrm{O}$ and $\mathrm{CuSO}_{4} \cdot 5 \mathrm{H}_{2} \mathrm{O}, \mathrm{FeSO}_{4} \cdot 7 \mathrm{H}_{2} \mathrm{O}$ and $\mathrm{Ni}\left(\mathrm{NO}_{3}\right)_{2} \cdot 6 \mathrm{H}_{2} \mathrm{O}$, were added simultaneously to the $\mathrm{ZnSO}_{4} \cdot 7 \mathrm{H}_{2} \mathrm{O}$, solution under continuous stirring to get homogeneous solutions. These mixtures (solution A) were placed in an ultrasonic cleaner operating at $57 \mathrm{kHz}$ for $2 \mathrm{~h}$. Simultaneously, $44 \mathrm{mmol} \mathrm{NaOH}$ solution was prepared in $440 \mathrm{ml}$ of deionized water (solution $\mathrm{B}$ ). Then solution B was added drop wise to solution A with constant stirring for $2 \mathrm{~h}$ until a $\mathrm{pH}$ of 13 was reached. The mixed solution was allowed to stand at room temperature for $18 \mathrm{~h}$. Subsequently, the solution was centrifuged and washed several times with ethanol and distilled water to remove residual and unwanted impurities. The final product was dried in a vacuum oven at $200^{\circ} \mathrm{C}$ for $1 \mathrm{~h}$ to yield $\mathrm{Fe} / \mathrm{Cu}$ and $\mathrm{Fe} / \mathrm{Ni}$-codoped $\mathrm{ZnO}$ powders.

Elemental analyses of the samples were carried out using scanning electron microscope (SEM) with EDX attachment. To evaluate the phase purity of the samples, XRD measurements were performed using a Philips PW 1710 and monochromatic $\mathrm{Cu}-\mathrm{K} \alpha(\lambda=1.54060 \AA)$ radiation operated at $40 \mathrm{kV}$ and $20 \mathrm{~mA}$ in the range of $10^{\circ}$ to $80^{\circ}$. The instrumental broadening including the instrumental symmetry was calibrated using a Si powder standard sample. The X-ray diffraction patterns were analyzed by means of the MAUD program using the Rietveld whole profile fitting method to determine the crystal structure and lattice parameters.

To study the electronic interaction near the optical band gap resulting from the addition of dopant atoms, diffuse reflectance UV-Vis measurements were performed using a Shimadzu UV-Vis spectrophotometer with an integrating sphere and a spectral reflectance standard in the wavelength range of $200-800 \mathrm{~nm}$. The diffuse reflectance, $R$, of the sample is related to the Kubelka-Munkfunction, $\mathrm{F}(\mathrm{R})$, according to the following equation: $F(R)=(1-R)^{2} / 2 R$ [30]. The energy band gap of the samples was calculated from the diffuse reflectance spectra by plotting the $F(R)^{2}$ as a function of energy and extrapolating to $\mathrm{F}(\mathrm{R})^{2}=0$.

Magnetic measurements were performed on Oxford Type $1.2 \mathrm{~T}$ vibrating sample magnetometer (VSM). These measurements were taken from 0 to \pm 1 Tesla field. To obtain information on electronic structure ESR was carried out using X-band JEOL JES-RE1X at room temperature. The shape and area of the ESR spectra were analyzed using standard numerical methods.

\section{Results}

To confirm the presence of $\mathrm{Fe}, \mathrm{Cu}$ and $\mathrm{Ni}$ ions in the synthesized nanocrystalline $\mathrm{ZnO}$ particles, EDX measurements were performed. Four different random areas in the sample were chosen and about the same $\mathrm{Fe}, \mathrm{Cu}$ and $\mathrm{Ni}$ concentration was obtained for all of them. This result suggested that the distribution of doping is homogeneously. The EDX data from concentrations of $\mathrm{Fe}, \mathrm{Cu}$ and $\mathrm{Ni}$ are listed in Table 1. It is seen that the amounts of $\mathrm{Fe}, \mathrm{Cu}$ and $\mathrm{Ni}$ incorporated in the samples are slightly lower than their nominal composition introduced in the synthesis.

The XRD patterns for $\mathrm{Zn}_{0.96} \mathrm{Fe}_{0.01} \mathrm{Cu}_{0.03} \mathrm{O}$ and $\mathrm{Zn}_{0.96}$ $\mathrm{Fe}_{0.01} \mathrm{Ni}_{0.03} \mathrm{O}$ samples are presented in Figure 1. Also shown the XRD patterns of $\mathrm{Zn}_{0.95} \mathrm{Fe}_{0.05} \mathrm{O}$ [31], $\mathrm{Zn}_{0.94}$ $\mathrm{Cu}_{0.06} \mathrm{O}$ [32], $\mathrm{Zn}_{0.95} \mathrm{Ni}_{0.05} \mathrm{O}$ [33] and undoped $\mathrm{ZnO}$ [34]. It has been observed that all of peaks of XRD pattern belong to the hexagonal lattice of $\mathrm{ZnO}$ with three most preferred orientations namely (100), (002) and (101). Most importantly, all of the XRD peaks were attributed to $\mathrm{ZnO}$ and no other undesired peaks were observed due to secondary phases or impurity phases within the detection limit of the X-ray diffractometer. From the $2 \Theta$ values, the inter-planar spacing $d$ of the peaks is calculated.

The values are listed in Table 2. A good agreement between the observed and the calculated $d$ values is found to exist indicated a suitability of unit cell parameters and the crystal structure.

The lattice constants, calculated from Rietveld refinement using MAUD programs, unit cell volume, the values ratio (c/a) are summarized in Table 2. The results are compared with those of Fe-doped $\mathrm{ZnO}$. The average crystallite size and strain were also obtained from Rietveld refinement of the X-ray diffraction patterns of the samples obtained by constructing Williamson-Hall plots [35] with different peaks for the same families. In the present study, (100), (002), (101), (102), (110), (103),

Table 1. EDX data of $\mathrm{Fe}-$, $\mathrm{Cu}$-, $\mathrm{Ni}$-doped $\mathrm{ZnO}$ and $\mathrm{Cu}-$ and Ni-codoped FeZnO nanoparticle.

\begin{tabular}{cccccc}
\hline Sample & $\mathrm{Fe}(\%)$ & $\mathrm{Cu}(\%)$ & $\mathrm{Ni}(\%)$ & $\mathrm{Zn}(\%)$ & $\mathrm{O}(\%)$ \\
\hline $\mathrm{Zn}_{0.95} \mathrm{Fe}_{0.05} \mathrm{O}$ & 4.64 & - & - & 32.62 & 62.74 \\
$\mathrm{Zn}_{0.94} \mathrm{Cu}_{0.06} \mathrm{O}$ & - & 5.69 & - & 31.24 & 63.07 \\
$\mathrm{Zn}_{0.95} \mathrm{Ni}_{0.05} \mathrm{O}$ & - & - & 4.86 & 42.32 & 52.82 \\
$\mathrm{Zn}_{0.96} \mathrm{Fe}_{0.01} \mathrm{Cu}_{0.03} \mathrm{O}$ & 1.02 & 2.96 & - & 42.71 & 53.31 \\
$\mathrm{Zn}_{0.96} \mathrm{Fe}_{0.01} \mathrm{Ni}_{0.03} \mathrm{O}$ & 1.35 & - & 3.23 & 42.60 & 52.82 \\
\hline
\end{tabular}




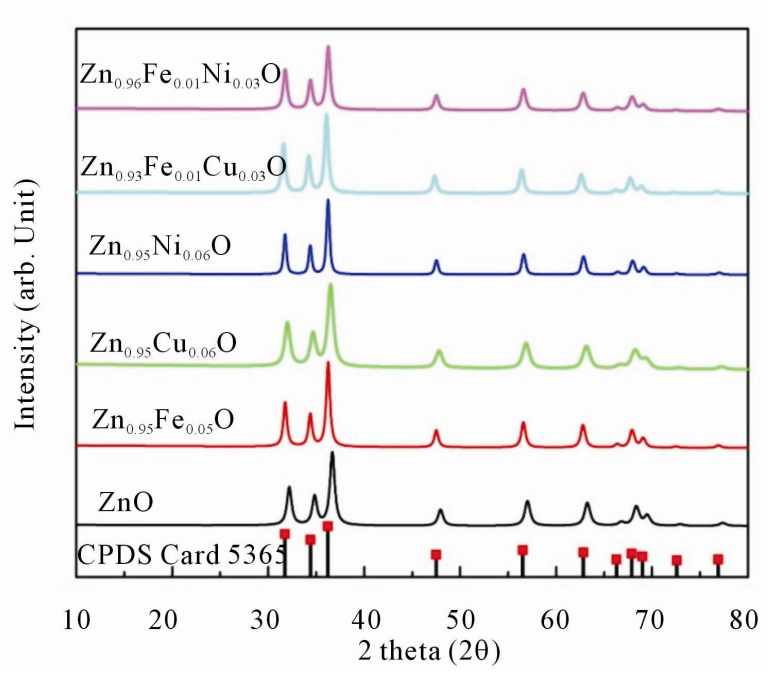

Figure 1. XRD patterns of $\mathrm{ZnO}, \mathrm{Zn}_{0.95} \mathrm{Fe}_{0.05} \mathrm{O}, \mathrm{Zn}_{0.94} \mathrm{Cu}_{0.06} \mathrm{O}$, $\mathrm{Zn}_{0.95} \mathrm{Ni}_{0.05} \mathrm{O}, \mathrm{Zn}_{0.96} \mathrm{Fe}_{0.01} \mathrm{Cu}_{0.03} \mathrm{O}$ and $\mathrm{Zn}_{0.96} \mathrm{Fe}_{0.01} \mathrm{Ni}_{0.03} \mathrm{O}$ nanoparticles.

and (112) peaks were used to construct the WilliamsonHall plot. From the linear fit to the data, the average crystallite size, $\langle D>$, was extracted from the y-intercept and the strain, $\varepsilon$, from the slope of the fit of:

$$
\beta \cos \theta=K \lambda /\langle D\rangle+2 \varepsilon \sin \theta
$$

In this calculation the strain was assumed to be uniform in all directions of the samples. The average crystallite size, $\langle D>$ and the strain, $\varepsilon$, are shown in Table 2. These results indicate that the $\left\langle D>\right.$ in the $\mathrm{Zn}_{0.96} \mathrm{Fe}_{0.01}$ $\mathrm{Cu}_{0.03} \mathrm{O}$ and $\mathrm{Zn}_{0.96} \mathrm{Fe}_{0.01} \mathrm{Ni}_{0.03} \mathrm{O}$ samples have a similar average crystallite size with $\mathrm{Zn}_{0.97} \mathrm{Fe}_{0.03} \mathrm{O}$. These data showed that the substitutional doping does not influence the crystal structure significantly.

To study the electronic interactions near the optical band gap region of $\mathrm{Zn}_{0.96} \mathrm{Fe}_{0.01} \mathrm{Cu}_{0.03} \mathrm{O}$ an $\mathrm{Zn}_{0.96} \mathrm{Fe}_{0.01}$ $\mathrm{Ni}_{0.03} \mathrm{O}$ samples diffuse-reflectance measurements were performed on the samples in the UV-Vis region at room temperature. All spectra were obtained in the range of 200 - $800 \mathrm{~nm}$. Figure 2 shows the diffuse-reflectance spectra, R, as a function of wavelength. The band gap energy of the doped $\mathrm{ZnO}$ samples was calculated from the diffuse-reflectance spectra by plotting the square of the Kubelka-Munk function $F(R)^{2}$ vs. the energy in electron volts. The linear part of the curve was extrapolated to $\mathrm{F}(\mathrm{R})^{2}=0$ to calculate the direct band gap energy. The Table 2 also shows the band of $\mathrm{Zn}_{0.96} \mathrm{Fe}_{0.01} \mathrm{Cu}_{0.03} \mathrm{O}$ and $\mathrm{Zn}_{0.96} \mathrm{Fe}_{0.01} \mathrm{Ni}_{0.03} \mathrm{O}$ samples. It is seen that the absorption edge is slightly different with the addition of $\mathrm{Cu}$ and $\mathrm{Ni}$ in Fe-doped $\mathrm{ZnO}$ sample compare to Fe-doped $\mathrm{ZnO}$ sample itself.

To gain insight into the oxidation state of the dopant cations involved in the spin coupling and site occupancy of the dopant ion in the host material, ESR spectra were

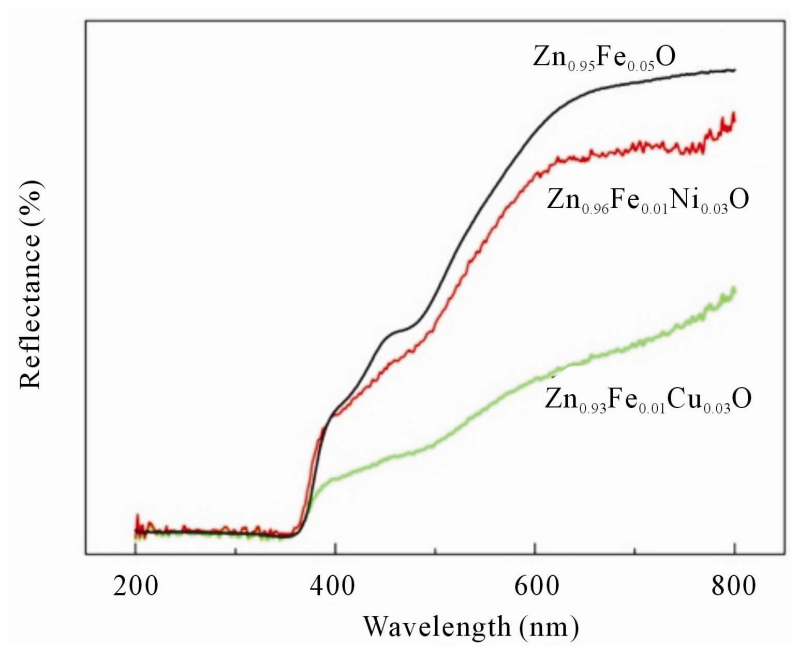

Figure 2. The diffuse-reflectance spectra of $\mathrm{Zn}_{0.96} \mathrm{Fe}_{0.01}$ $\mathrm{Cu}_{0.03} \mathrm{O}$ and $\mathrm{Zn}_{0.96} \mathrm{Fe}_{0.01} \mathrm{Ni}_{0.03} \mathrm{O}$ compared with $\mathrm{Zn}_{0.95} \mathrm{Fe}_{0.05} \mathrm{O}$ nanoparticles.

measured at room temperature. Typical ESR spectra of both the $\mathrm{Zn}_{0.96} \mathrm{Fe}_{0.01} \mathrm{Cu}_{0.03} \mathrm{O}$ and $\mathrm{Zn}_{0.96} \mathrm{Fe}_{0.01} \mathrm{Ni}_{0.03} \mathrm{O}$ particles are provided in Figure 3. For interpretation of $\mathrm{Zn}_{0.96} \mathrm{Fe}_{0.01} \mathrm{Cu}_{0.03} \mathrm{O}$ and $\mathrm{Zn}_{0.96} \mathrm{Fe}_{0.01} \mathrm{Ni}_{0.03} \mathrm{O}$ results a comparison with $\mathrm{Fe}-$, $\mathrm{Ni}$ - and $\mathrm{Cu}$-doped $\mathrm{ZnO}$ ESR spectra was also instructive. In $\mathrm{Zn}_{0.95} \mathrm{Fe}_{0.05} \mathrm{O}$ the ESR signal can be considered as a superposition of two overlapping signals, a broad and intense signal attributed to $\mathrm{Fe}^{2+}$ and another weak and narrow signal assigned to $\mathrm{Fe}^{3+}[31,33]$. In the case of $\mathrm{Zn}_{0.95} \mathrm{Ni}_{0.05} \mathrm{O}$, the ESR spectra had similar features, which exhibited two overlapping resonance peaks. One peak corresponded to the broad resonance while the other peak located at higher magnetic field was much narrower. The linewidth and the g-values of the broad signal in our $\mathrm{Zn}_{0.95} \mathrm{Ni}_{0.05} \mathrm{O}$ was consistent with the line shape and position of the previously reported Ni-doped $\mathrm{ZnO}$ samples $[33,36]$ and have been attributed to a ferromagnetic resonance due to $\mathrm{Ni}^{2+}$ ions. A comparison of the g-values of the narrow ESR signal with the ESR signals of $\mathrm{Ni}$ in $\mathrm{Li}_{1-\mathrm{X}} \mathrm{Ni}_{1+\mathrm{X}} \mathrm{O}_{2}$ [37,38], $\mathrm{SnO}_{2}$ [39] and $\mathrm{TiO}_{2}$ [40], which have g-values in the range of 2.13 2.18 , suggests that the narrow resonance in our $\mathrm{Zn}_{0.95}$ $\mathrm{Ni}_{0.05} \mathrm{O}$ samples is attributable to paramagnetic $\mathrm{Ni}^{3+}$ ion centers.

The electronic configuration of $\mathrm{Cu}^{2+}$ ion is $3 \mathrm{~d}^{9}$ and the electronic ground state is ${ }^{3} \mathrm{~S}_{1 / 2}$. The only natural isotope is ${ }^{63} \mathrm{Cu}$, which has nuclear spin $3 / 2$. The ESR spectrum of $\mathrm{Zn}_{0.94} \mathrm{Cu}_{0.06} \mathrm{O}$ sample shown in Figure 3 revealed the presence of broad signal, which is superimposed on poor-resolved quadruplet signals and a pronounce narrow resonance. The broad signal at $\mathrm{g}$ value of 2.05 is associated with $\mathrm{Cu}^{2+}$ interacting with nearby $\mathrm{Cu}^{2+}$ via dipole interaction [41] whereas a narrow signal at $g$ value of 1.98 could be attributed to an unpaired electron trap- 
Table 2. The The lattice constants, unit cell volume, ratio of lattice parameters, interplanar spacing, average crystallite size, strain and band gap energy of $\mathrm{Zn}_{0.95} \mathrm{Fe}_{0.05} \mathrm{O}, \mathrm{Zn}_{0.94} \mathrm{Cu}_{0.06} \mathrm{O}, \mathrm{Zn}_{0.95} \mathrm{Ni}_{0.05} \mathrm{O}, \mathrm{Zn}_{0.96} \mathrm{Fe}_{0.01} \mathrm{Cu}_{0.03} \mathrm{O}$, and $\mathrm{Zn}_{0.96} \mathrm{Fe}_{0.01} \mathrm{Ni}_{0.03} \mathrm{O}$ nanoparticle.

\begin{tabular}{ccccccccc}
\hline Sample & $\mathrm{a}=\mathrm{b}(\AA)$ & $\mathrm{c}(\AA)$ & volume $\left(\AA^{3}\right)$ & $\mathrm{c} / \mathrm{a}$ & $\mathrm{d}_{101}(\AA)$ & $<D>\mathrm{nm}$ & $\varepsilon\left(\times 10^{-4}\right)$ & $\mathrm{Eg}(\mathrm{eV})$ \\
\hline $\mathrm{Zn}_{0.95} \mathrm{Fe}_{0.05} \mathrm{O}$ & 3.2555 & 5.2184 & 47.8781 & 1.6029 & 2.4805 & 21 & 21.2 & 3.29 \\
$\mathrm{Zn}_{0.94} \mathrm{Cu}_{0.06} \mathrm{O}$ & 3.2350 & 5.1810 & 46.9570 & 1.6015 & 2.4644 & 18 & 47.0 & 3.32 \\
$\mathrm{Zn}_{0.95} \mathrm{Ni}_{0.05} \mathrm{O}$ & 3.2370 & 5.1890 & 46.7592 & 1.6030 & 2.4664 & 27 & 33.9 & 3.28 \\
$\mathrm{Zn}_{0.96} \mathrm{Fe}_{0.01} \mathrm{Cu}_{0.03} \mathrm{O}$ & 3.2563 & 5.2205 & 47.9388 & 1.6032 & 2.4812 & 19 & 9.16 & 3.33 \\
$\mathrm{Zn}_{0.96} \mathrm{Fe}_{0.01} \mathrm{Ni}_{0.03} \mathrm{O}$ & 3.2553 & 5.2186 & 47.8938 & 1.6031 & 2.4804 & 18 & 13.70 & 3.36 \\
\hline
\end{tabular}

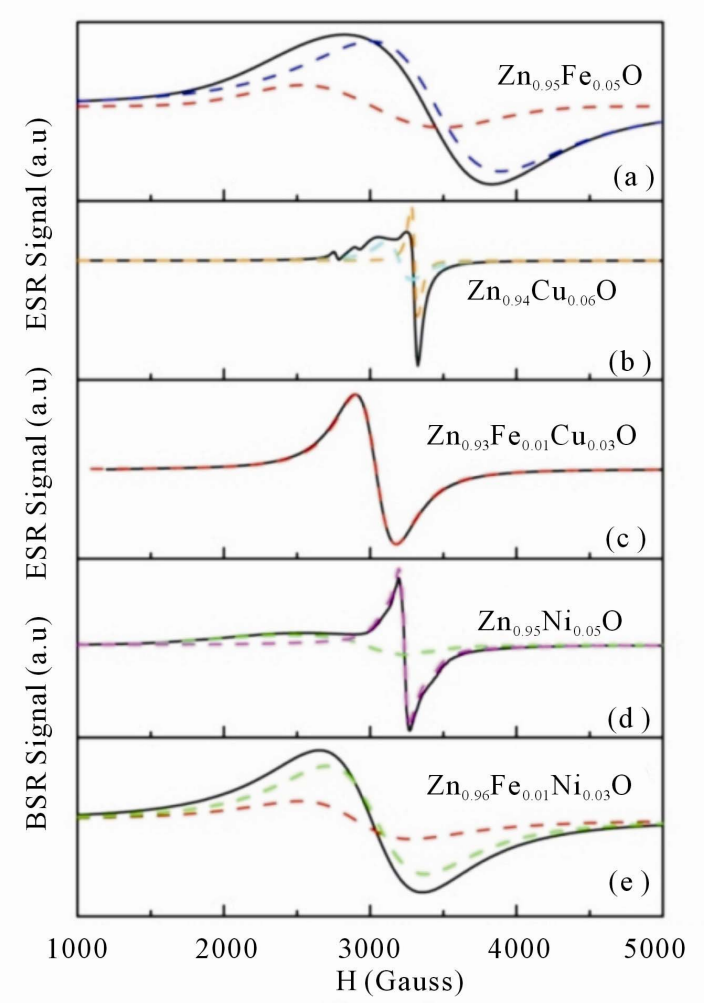

Figure 3. The electron spin resonance spectra of $\mathrm{Zn}_{0.96} \mathrm{Fe}_{0.01}$ $\mathrm{Cu}_{0.03} \mathrm{O}$ and $\mathrm{Zn}_{0.96} \mathrm{Fe}_{0.01} \mathrm{Ni}_{0.03} \mathrm{O}$ compared with $\mathrm{Zn}_{0.95} \mathrm{Fe}_{0.05} \mathrm{O}$, $\mathrm{Zn}_{0.94} \mathrm{Cu}_{0.06} \mathrm{O}$, and $\mathrm{Zn}_{0.95} \mathrm{Ni}_{0.05} \mathrm{O}$ nanoparticles.

ped on an oxygen vacancy site [42-52].

Comparing the ESR spectra of $\mathrm{Zn}_{0.95} \mathrm{Fe}_{0.05} \mathrm{O}$ and $\mathrm{Zn}_{0.94}$ $\mathrm{Cu}_{0.06} \mathrm{O}$ with that of $\mathrm{Zn}_{0.96} \mathrm{Fe}_{0.01} \mathrm{Cu}_{0.03} \mathrm{O}$, the line width and the g-value of $\mathrm{Zn}_{0.96} \mathrm{Fe}_{0.01} \mathrm{Cu}_{0.03} \mathrm{O}$ can be attributed to $\mathrm{Fe}^{2+}$, since the g-value observed here does not agree with the reported value for $\mathrm{Cu}^{2+}$. In addition, hyperfine structure due to ${ }^{63} \mathrm{Cu}$ and ${ }^{63} \mathrm{Cu}$ nuclei necessary for identification of $\mathrm{Cu}$-related center was not observed. So the peak observed here would not be attributed to the $\mathrm{Cu}$ ions themselves.

It is apparent from Figure 3 that the two resonances of $\mathrm{Zn}_{0.96} \mathrm{Fe}_{0.01} \mathrm{Ni}_{0.03} \mathrm{O}$ are too close to be separated with confidence. We have carefully studied the line signal and found that the line-width and the line intensity can be deconvoluted in $\mathrm{Fe}^{2+}$ and $\mathrm{Ni}^{2+}$ signals. Although, it was reported that the g-value of $\mathrm{Ni}$ metallic species is centered at 2.2 [53], the presence of Ni metallic might be ruled out since the line width of this species is much broader than that of our ESR spectra of $\mathrm{Zn}_{0.96} \mathrm{Fe}_{0.01}$ $\mathrm{Ni}_{0.03} \mathrm{O}$. The g-values, total number of spins associated with each signals and the line width are quite variable as shown in Table 3.

The room temperature ferromagnetic behavior of both the $\mathrm{Zn}_{0.96} \mathrm{Fe}_{0.01} \mathrm{Cu}_{0.03} \mathrm{O}$ and $\mathrm{Zn}_{0.96} \mathrm{Fe}_{0.01} \mathrm{Ni}_{0.03} \mathrm{O}$ particles in the magnetic field range from 0 to $\pm 1 \mathrm{~T}$ using VSM measurements have been shown in Figure 4. The magnetization is plotted as a function of magnetic field for different dopant ions incorporated in Fe-doped $\mathrm{ZnO}$ particles. The diamagnetic contribution from the sample holder has already been subtracted to estimate the actual ferromagnetic contribution of each sample. Also shown in Figure 4 the magnetization of $\mathrm{Zn}_{0.95} \mathrm{Fe}_{0.05} \mathrm{O}, \mathrm{Zn}_{0.94}$ $\mathrm{Cu}_{0.06} \mathrm{O}$ and $\mathrm{Zn}_{0.95} \mathrm{Ni}_{0.05} \mathrm{O}$. The comparative $\mathrm{M}(\mathrm{H})$ loops showed that, the $\mathrm{Zn}_{0.96} \mathrm{Fe}_{0.01} \mathrm{Ni}_{0.03} \mathrm{O}$ exhibits higher magnetization than that of $\mathrm{Zn}_{0.97} \mathrm{Fe}_{0.03} \mathrm{O}$ as well as $\mathrm{Zn}_{0.95}$ $\mathrm{Ni}_{0.05} \mathrm{O}$. The same result was also observed in $\mathrm{Zn}_{0.96} \mathrm{Fe}_{0.01}$ $\mathrm{Cu}_{0.03} \mathrm{O}$. In the case of $\mathrm{Zn}_{0.96} \mathrm{Fe}_{0.01} \mathrm{Cu}_{0.03} \mathrm{O}$ sample a coercive field $\left(\mathrm{H}_{\mathrm{C}}\right)$ and the remnant magnetization $\left(\mathrm{M}_{\mathrm{R}}\right)$ are found to be $554 \mathrm{Oe}$ and $0.012 \mathrm{emu} / \mathrm{g}$, while for $\mathrm{Zn}_{0.96} \mathrm{Fe}_{0.01} \mathrm{Ni}_{0.03} \mathrm{O}$ smaller values are observed, namely $120 \mathrm{Oe}$ and $0.004 \mathrm{emu} / \mathrm{g}$. However, the saturation magnetization for $\mathrm{Ni}$ incorporation in Fe-doped $\mathrm{ZnO}$ is clearly higher than that of $\mathrm{Cu}$ co-doping.

The mechanism responsible for the observed ferromagnetism at room temperature in transition metaldoped $\mathrm{ZnO}$ is also not clear and has been debated over the years. Several explanations are discussed below. Nevertheless a few researchers have claimed to observe ferromagnetic behavior arising only from a secondary phase and not from the material itself. The results of the XRD and EDX measurements in our samples demonstrate that the dopant ion was incorporated into the wurtzite lattice at $\mathrm{Zn}$ sites forming a solid solution instead of precipitates. However, a secondary phase might 
Table 3. The g value, linewidth $\left(\Delta \mathrm{H}_{\mathrm{pp}}\right)$, and peak area of $\mathrm{Zn}_{0.96} \mathrm{Fe}_{0.01} \mathrm{Cu}_{0.03} \mathrm{O}$ and $\mathrm{Zn}_{0.96} \mathrm{Fe}_{0.01} \mathrm{Ni}_{0.03} \mathrm{O}$ compared with $\mathrm{Zn}_{0.95} \mathrm{Fe}_{0.05}$ $\mathrm{O}, \mathrm{Zn}_{0.94} \mathrm{Cu}_{0.06} \mathrm{O}$, and $\mathrm{Zn}_{0.95} \mathrm{Ni}_{0.05} \mathrm{O}$ nanoparticle.

\begin{tabular}{ccccccc}
\hline Sample & g value & $\Delta \mathrm{H}_{\mathrm{PP}}($ Gauss $)$ & Area $\left(\times 10^{6}\right)($ a.u $)$ & g value & $\Delta \mathrm{H}_{\mathrm{PP}}($ Gauss $)$ & Area $\left(\times 10^{5}\right)(\mathrm{a} . \mathrm{u})$ \\
\hline $\mathrm{Zn}_{0.95} \mathrm{Fe}_{0.05} \mathrm{O}$ & 2.2378 & 1074.54 & 4.73 & 2.0077 & 826.38 & 10.50 \\
$\mathrm{Zn}_{0.94} \mathrm{Cu}_{0.06} \mathrm{O}$ & 2.1770 & 312.19 & 23.90 & 2.1460 & 62.35 & 6.07 \\
$\mathrm{Zn}_{0.95} \mathrm{Ni}_{0.05} \mathrm{O}$ & 2.5795 & 801.38 & 4.71 & 2.1501 & 70.32 & 35.70 \\
$\mathrm{Zn}_{0.96} \mathrm{Fe}_{0.01} \mathrm{Cu}_{0.03} \mathrm{O}$ & 2.2134 & 286.05 & 6.78 & - & - & - \\
$\mathrm{Zn}_{0.96} \mathrm{Fe}_{0.01} \mathrm{Ni}_{0.03} \mathrm{O}$ & 2.3208 & 795.51 & 14.25 & 2.2137 & 698.22 & 31.41 \\
\hline
\end{tabular}

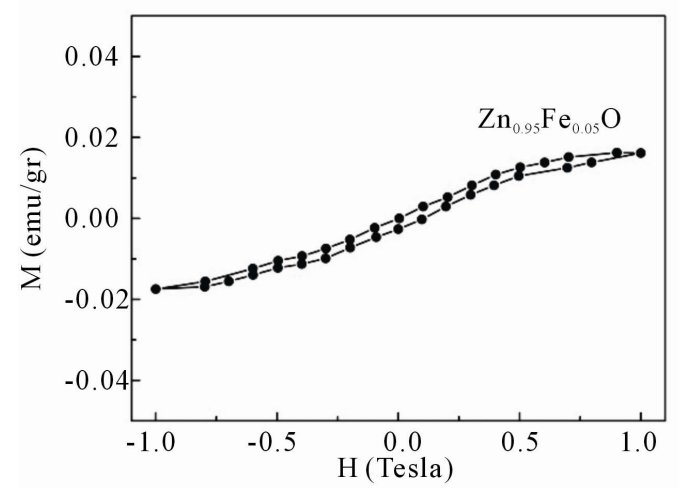

(a)

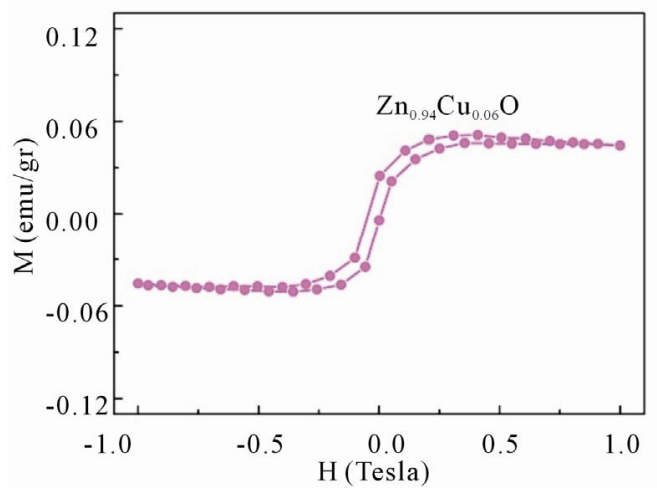

(b)

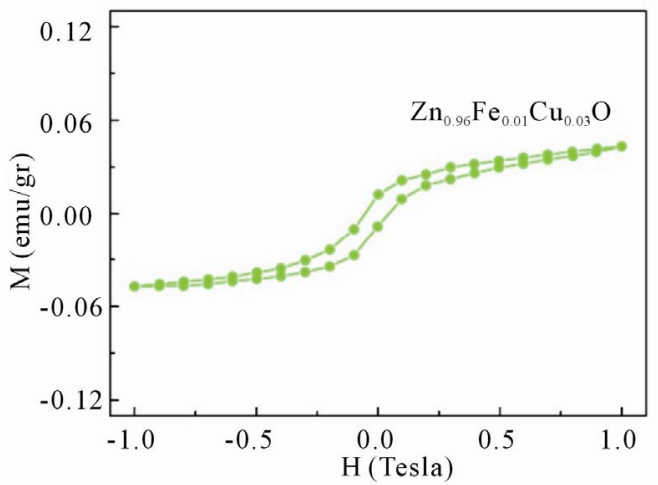

(d)

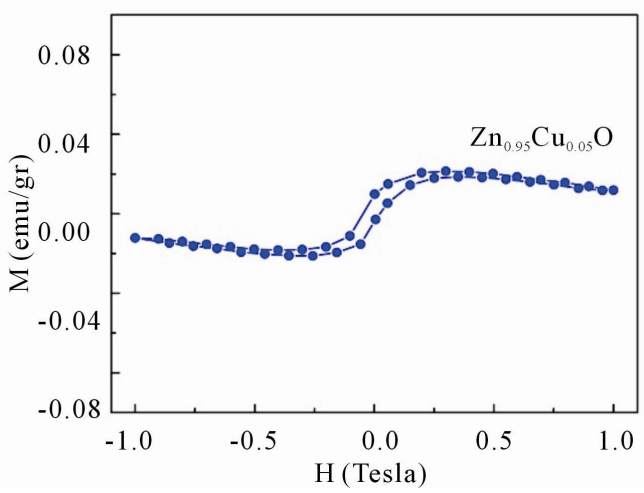

(c)

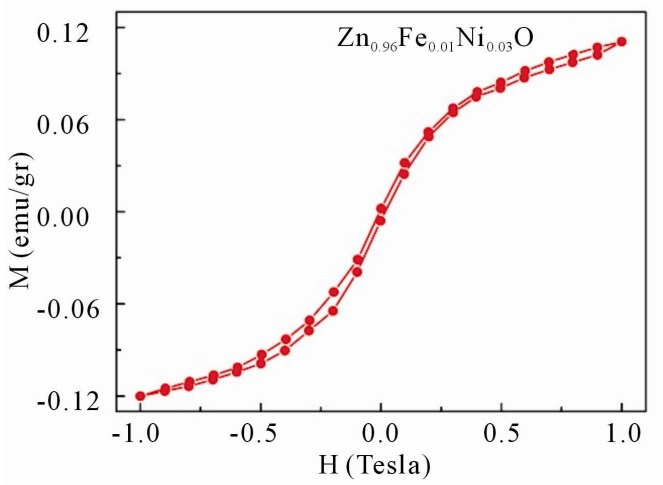

(e)

Figure 4. The room temperature ferromagnetic of $\mathrm{Zn}_{0.96} \mathrm{Fe}_{0.01} \mathrm{Cu}_{0.03} \mathrm{O}$ and $\mathrm{Zn}_{0.96} \mathrm{Fe}_{0.01} \mathrm{Ni}_{0.03} \mathrm{O}$ compared with $\mathrm{Zn}_{0.95} \mathrm{Fe}_{0.05} \mathrm{O}$, $\mathrm{Zn}_{0.94} \mathrm{Cu}_{0.06} \mathrm{O}$, and $\mathrm{Zn}_{0.95} \mathrm{Ni}_{0.05} \mathrm{O}$ nanoparticles. 
exist in the sample even though it was not detected in our XRD spectra. Thus, it is useful to consider all possible ferromagnetic impurity phases that might be present in both samples. It is known that $\mathrm{Cu}$-related oxides such as $\mathrm{CuO}, \mathrm{Cu}_{2} \mathrm{O}$ or $\mathrm{Cu}$ clustering could not contribute to the room temperature ferromagnetism, because none of them exhibit ferromagnetism above room temperature [54-56]. Therefore the ferromagnetism behavior observed in our $\mathrm{Cu}$-doped samples studied here does not seem to be related with the presence of any secondary phases or $\mathrm{Cu}$ clusters, while $\mathrm{Cu}$ clusters and its oxides are generally considered to be non-ferromagnetic and could not contribute to the room temperature ferromagnetic. In the case of Fe-doped samples nearly all possible Fe-based oxides, such as $\mathrm{FeO}$ and $\mathrm{Fe}_{2} \mathrm{O}_{3}$ are antiferromagnetic with $\mathrm{T}_{\mathrm{N}}$ values of 198 and $963 \mathrm{~K}$, respectively [57,58]. The exception to this is $\mathrm{Fe}_{3} \mathrm{O}_{4}$, which is ferromagnetic with a $\mathrm{T}_{\mathrm{c}}$ of approximately $858 \mathrm{~K}$ [59]. Another secondary phase that can be found in Fe-doped $\mathrm{ZnO}$ samples is $\mathrm{ZnFe}_{2} \mathrm{O}_{4}$. However, this phase is antiferromagnetic and can be excluded as the origin of room temperature ferromagnetic in our samples. In the case of $\mathrm{Ni}$ co-doping, the formation of secondary phase such as $\mathrm{NiO}$ is a unlikely source of ferromagnetism as $\mathrm{NiO}$ is antiferromagnetic in nature with $\mathrm{T}_{\mathrm{N}}$ values of $523 \mathrm{~K}$ [60] and $5 \mathrm{~K}$ [61] for bulk- and nanocrystalline $\mathrm{NiO}$, respectively. Accordingly, the ferromagnetism behavior observed in our $\mathrm{Zn}_{0.96} \mathrm{Fe}_{0.01} \mathrm{Cu}_{0.03}$ $\mathrm{O}$ and $\mathrm{Zn}_{0.96} \mathrm{Fe}_{0.01} \mathrm{Ni}_{0.03} \mathrm{O}$ particles studied here does not seem to be related with the presence of any secondary phases.

There is also an emerging consensus that ferromagnetic behavior in transition metal-doped $\mathrm{ZnO}$ is correlated with defects such as oxygen or zinc vacancies [62-64]. Karmakar et al. [11] investigated the origin of ferromagnetism in Fe-doped $\mathrm{ZnO}$ using local probe measurements such as ESR and Mössbauer spectroscopy. The results revealed that the Fe ions are present in both $\mathrm{Fe}^{2+}$ and $\mathrm{Fe}^{3+}$ valence states. The presence of uncoupled $\mathrm{Fe}^{3+}$ ions is possibly due to hole doping in the system, which was caused by cation (i.e., $\mathrm{Zn}$ ) vacancies. By comparing the ESR measurements from our sample with the results obtained from Karmakar et al. [11] it is confirmed that the ferromagnetism observed in our $\mathrm{Zn}_{0.97}$ $\mathrm{Fe}_{0.03} \mathrm{O}$ sample was due to the presence of $\mathrm{Fe}$ atoms in the form of $\mathrm{Fe}^{2+}$ ions and $\mathrm{Fe}^{3+}$ ions.

According to Karmakar et al. [11] a cation vacancy near $\mathrm{Fe}$ can promote $\mathrm{Fe}^{2+}$ into $\mathrm{Fe}^{3+}$ and also mediate the $\mathrm{Fe}^{2+}-\mathrm{Fe}^{2+}$ exchange interaction. Moreover, since the transition metal ion is slightly higher side towards cationic percolation threshold, $\mathrm{Fe}^{2+}-\mathrm{Fe}^{3+}$ exchange interaction may also possible. Viswanatha et al. [65] investigated the origin of ferromagnetism in $\mathrm{FeCu}$-codoped $\mathrm{ZnO}$ experimentally as well as theoretically. Their results revealed that the $\mathrm{Fe}$ ions are present in both $\mathrm{Fe}^{2+}$ and $\mathrm{Fe}^{3+}$ valence states, with the concentration of trivalent state increased with increasing $\mathrm{Cu}$ doping and redox-like pairs $\mathrm{Fe}^{2+}+$ $\mathrm{Cu}^{2+} \Leftrightarrow \mathrm{Fe}^{3+}+\mathrm{Cu}^{1+}$ can be occurred to stabilize the ferromagnetism in codoped system. They believed that the ferromagnetism of this system is ascribed to a double-exchange interaction between the Fe atoms mediated by the $\mathrm{Cu}$ atom. It is obvious from ESR spectra of $\mathrm{Zn}_{0.96} \mathrm{Fe}_{0.01} \mathrm{Cu}_{0.03} \mathrm{O}$ show the presence of $\mathrm{Fe}^{2+}$ ion and the absence of $\mathrm{Cu}^{2+}$ ion. However, our EDX result shows the presence of $\mathrm{Cu}$ atom in our $\mathrm{Zn}_{0.96} \mathrm{Fe}_{0.01} \mathrm{Cu}_{0.03} \mathrm{O}$. These results suggested that the oxidation state of $\mathrm{Cu}$ is +1 , since $\mathrm{Cu}$ in the +1 state has no unpaired spin. Usually, a $\mathrm{Cu}$ ion will contribute to the net ferromagnetic moment only if it is in the +2 state. Interestingly, the $\mathrm{Zn}_{0.96} \mathrm{Fe}_{0.01}$ $\mathrm{Cu}_{0.03} \mathrm{O}$ sample shows an evidence of ferromagnetic order. Therefore we believed that a small amount of $\mathrm{Fe}^{3+}$ and $\mathrm{Cu}^{2+}$ ions would be found in our sample to neutralize the charge imbalance, although both ions $\left(\mathrm{Fe}^{3+}\right.$ and $\left.\mathrm{Cu}^{2+}\right)$ were not detected in our ESR spectra. Comparing the XRD, EDX, VSM and ESR results for $\mathrm{Zn}_{0.96} \mathrm{Fe}_{0.01} \mathrm{Cu}_{0.03} \mathrm{O}$ with $\mathrm{Zn}_{0.95} \mathrm{Fe}_{0.05} \mathrm{O}, \mathrm{Zn}_{0.94} \mathrm{Cu}_{0.06} \mathrm{O}$ and the results obtained in the literature, we conclude that $\mathrm{Fe}^{2+}, \mathrm{Cu}^{1+}, \mathrm{Fe}^{3+}$ and $\mathrm{Cu}^{2+}$ are presence in our $\mathrm{Zn}_{0.96} \mathrm{Fe}_{0.01} \mathrm{Cu}_{0.03} \mathrm{O}$ sample and have played the important role in obtaining the room temperature ferromagnetism.

In the case of $\mathrm{Zn}_{0.96} \mathrm{Fe}_{0.01} \mathrm{Ni}_{0.03} \mathrm{O}$, the bent nature of the curve exhibits a shallow ferromagnetism in our sample. The ferromagnetism could arise due to possible reason: 1) secondary phase or clustering of metallic or 2) the presence of charge carriers, or 3) the formation of defect structures such as oxygen- and zinc vacancies. It is already discussed above that the formation of secondary phase is unlikely. Moreover, from the ESR spectra of $\mathrm{Zn}_{0.96} \mathrm{Fe}_{0.01} \mathrm{Ni}_{0.03} \mathrm{O}$ the presence of $\mathrm{Ni}$ metallic might be ruled out. In addition the ESR measurement exhibits superposition of $\mathrm{Fe}^{2+}$ and $\mathrm{Ni}^{2+}$ signals. It is also known that the presence of $\mathrm{Ni}$ in $\mathrm{ZnO}$ nanoparticle could enhance the magnetic $d-d$ exchange interaction between the magnetic moment of $\mathrm{Ni}^{2+}$ contribute for the ferromagnetic state [66]. Thus the observed ferromagnetism in the $\mathrm{Zn}_{0.96}$ $\mathrm{Fe}_{0.01} \mathrm{Ni}_{0.03} \mathrm{O}$ could be considered as a result of the exchange interaction between conductive electron with local spin polarized electron on the $\mathrm{Ni}^{2+}$ or $\mathrm{Fe}^{2+}$ ions. In some reported transition metal doped $\mathrm{ZnO}$ systems, bound magnetic polaron (BMP) models are widely proposed mechanisms to explain the presence of room temperature ferromagnetism. The BMP model was used to explain room temperature ferromagnetism in semiconducting as well as insulating materials [67]. Other studies reported that defects and oxygen vacancies are common in Ni-doped $\mathrm{ZnO}$ nanostructures and are responsible for the formation of BMP [68]. However, the oxygen vacancy signal was not observed in $\mathrm{Zn}_{0.96} \mathrm{Fe}_{0.01} \mathrm{Ni}_{0.03} \mathrm{O}$ ESR spectra. Therefore, the conductive electron with local 
spin polarized electron exchange interaction is the more probable mechanism in the present investigation.

\section{Conclusion}

In conclusion, the room temperature ferromagnetism of $\mathrm{Zn}_{0.96} \mathrm{Fe}_{0.01} \mathrm{Cu}_{0.03} \mathrm{O}$ and $\mathrm{Zn}_{0.96} \mathrm{Fe}_{0.01} \mathrm{Ni}_{0.03} \mathrm{O}$ nanoparticles were observed. Several assumptions have been addressed to explain room temperature ferromagnetism: the role of secondary phases, metallic clusters and defect-induced ferromagnetism. A detailed analysis of XRD, EDX, UV$\mathrm{Vis}$ and ESR measurements revealed that the formation of secondary phases and metallic clusters in $\mathrm{Zn}_{0.96}$ $\mathrm{Fe}_{0.01} \mathrm{Cu}_{0.03} \mathrm{O}$ and $\mathrm{Zn}_{0.96} \mathrm{Fe}_{0.01} \mathrm{Ni}_{0.03} \mathrm{O}$ nanoparticles were not responsible for the room temperature ferromagnetism. In $\mathrm{Zn}_{0.96} \mathrm{Fe}_{0.01} \mathrm{Cu}_{0.03} \mathrm{O}$ nanoparticles ESR and EDX analysis revealed that $\mathrm{Fe}^{2+}$ ions and $\mathrm{Cu}^{1+}$ were present. However, to neutralize the charge imbalance we believed that a small amount of $\mathrm{Fe}^{3+}$ and $\mathrm{Cu}^{2+}$ ions would be found in our sample and have played the important role in obtaining the room temperature ferromagnetism. In $\mathrm{Zn}_{0.96}$ $\mathrm{Fe}_{0.01} \mathrm{Ni}_{0.03} \mathrm{O}$ the conductive electron with local spin polarized electron exchange interaction is the more probable mechanism for the origin of room temperature ferromagnetism.

\section{REFERENCES}

[1] J. H. Shim, T. Hwang, S. Lee, J. H. Park and S.-J. Han, "Origin of Ferromagnetism in Fe- and Cu-Codoped $\mathrm{ZnO}$," Applied Physics Letters, Vol. 86, No. 8, 2005, Article ID: 082503. doi:10.1063/1.1868872

[2] S. A. Wolf, D. D. Awschalom, R. A. Buhrman, J. M. Daughton, S. Von Molnar, M. L. Roukes, A. Y. Chichelkanova and D. M. Treger, "Spintronics: A Spin-Based Electronics Vision for the Future," Science, Vol. 294, No. 5546, 2001, pp. 1488-1495. doi:10.1126/science.1065389

[3] S. Ghosh and K. Mandal, "Study of $\mathrm{Zn}_{1-\mathrm{x}} \mathrm{Co}_{\mathrm{x}} \mathrm{O}(0.02<\mathrm{x}$ $<0.08)$ Dilute Magnetic Semiconductor Prepared by Mechanosynthesis Route," Journal of Magnetism and Magnetic Materials, Vol. 322, No. 14, 2010, pp. 1979-1984. doi:10.1016/j.jmmm.2010.01.017

[4] H. Ohno, "Making Nonmagnetic Semiconductors Ferromagnetic," Science, Vol. 281, No. 5379, 1998, pp. 951956. doi:10.1126/science.281.5379.951

[5] G. A. Prinz, "Magnetoelectronics," Science, Vol. 282, No. 5394, 1998, pp. 1660-1663. doi:10.1126/science.282.5394.1660

[6] L. B. Duan, W. G. Chu, J. Yu, Y. C. Wang, L. N. Zhang, G. Y. Liu, J. K. Liang and G. H. Rao, "Structural and Magnetic Properties of $\mathrm{Zn}_{1-\mathrm{x}} \mathrm{Co}_{\mathrm{x}} \mathrm{O}(0<\mathrm{x}<0.30)$ Nanoparticles," Journal of Magnetism and Magnetic Materials, Vol. 320, No. 8, 2008, pp. 1573-1581. doi:10.1016/j.jmmm.2008.01.009

[7] T. Dietl, H. Ohno, F. Matsukura, J. Cibert and D. Ferrand, "Zener Model Description of Ferromagnetism in ZincBlende Magnetic Semiconductors," Science, Vol. 287, No.
5455, 2000, pp. 1019-1022. doi:10.1126/science.287.5455.1019

[8] X. Y. Xu and C. B. Cao, "Structure and Ferromagnetic Properties of Co-Doped ZnO Powders," Journal of Magnetism and Magnetic Materials, Vol. 321, No. 14, 2009, pp. 2216-2219. doi:10.1016/j.jmmm.2009.01.017

[9] J. M. Wesselinowa and A. T. Apostolov, "A Possibility to Obtain Room Temperature Ferromagnetism by Transition Metal Doping of ZnO Nanoparticles," Journal of Applied Physics, Vol. 107, No. 5, 2010, Article ID: 053917. doi:10.1063/1.3329457

[10] P. K. Sharma, R. K. Dutta, A. C. Pandey, S. Layek and H. C. Verma, "Effect of Iron Doping Concentration on Magnetic Properties of ZnO Nanoparticles," Journal of Magnetism and Magnetic Materials, Vol. 321, No. 17, 2009, pp. 2587-2591. doi:10.1016/j.jmmm.2009.03.043

[11] D. Karmakar, S. K. Mandal, R. M. Kadam, P. L. Paulose, A. K. Rajarajan, T. K. Nath, A. K. Das, I. Dasgupta and G. P. Das, "Ferromagnetism in Fe-Doped ZnO Nanocrystals: Experiment and Theory," Physical Review B, Vol. 75, No. 14, 2007, Article ID: 144404. doi:10.1103/PhysRevB.75.144404

[12] M. L. Dinesha, H. S. Jayanna, S. Ashoka and G. T. Chandrappa. J. Op-toel. Adv. Mater., Vol. 11, 2009, p. 964.

[13] S. K. Mandal, A. K. Das, T. K. Nath, D. Karmakar and B. Satpati, "Microstructural and Magnetic Properties of $\mathrm{ZnO}$ : $\mathrm{TM}(\mathrm{TM}=\mathrm{Co}, \mathrm{Mn})$ Diluted Magnetic Semiconducting Nanoparticles," Journal of Applied Physics, Vol. 100, No. 10, 2006, Article ID: 104315. doi:10.1063/1.2360387

[14] B. Martínez, F. Sandiumenge, L. Balcells, J. Arbiol, F. Sibieude and C. Monty, "Structure and Magnetic Properties of Co-Doped ZnO Nanoparticles," Physical Review $B$, Vol. 72, No. 16, 2005, Article ID: 165202 . doi:10.1103/PhysRevB.72.165202

[15] L. B. Duan, G. H. Rao, J. Yu and Y. C. Wang, "Ferromagnetism of Lightly Co-Doped ZnO Nanoparticles," Solid State Communications, Vol. 145, No. 11, 2008, pp. 525528. doi:10.1016/j.ssc.2008.01.014

[16] G. J. Huang, J. B. Wang, X. L. Zhong, G. C. Zhou and H. L. Yan, "Synthesis, Structure, and Room-Temperature Ferromagnetism of Ni-Doped ZnO Nanoparticles," Journal of Materials Science, Vol. 42, No. 15, 2007, pp. 6464 6468. doi:10.1007/s10853-006-1256-4

[17] Z. X. Cheng, X. L. Wang, S. X. Dou, K. Otawa, H. Kimura and P. Munroe, "Synthesis, Structure, and Room-Temperature Ferromagnetism of Ni-Doped ZnO Nanoparticles," Journal of Physics D, Vol. 40, No. 21, 2007, p. 6518. doi:10.1088/0022-3727/40/21/008

[18] P. K. Sharma, K. Prashant, R. K. Dutta and K. Ranu, "Effect of Nickel Doping Concentration on Structural and Magnetic Properties of Ultrafine Diluted Magnetic Semiconductor ZnO Nanoparticles," Journal of Magnetism and Magnetic Materials, Vol. 321, No. 20, 2009, pp. 3457-3461. doi:10.1016/j.jmmm.2009.06.055

[19] J. Luo, J. K. Liang, Q. L. Liu, F. S. Liu, Y. Zhang, B. J. Sun and G. H. Rao, "Structure and Magnetic Properties of Mn-Doped ZnO Nanoparticles," Journal of Applied Physics, Vol. 97, No. 8, 2005, Article ID: 086106. 
doi:10.1063/1.1873058

[20] J. B. Wang, G. J. Huang, X. L. Zhong, L. Z. Sun, Y. C. Zhou and E. H. Liu, "Raman Scattering and High Temperature Ferromagnetism of Mn-Doped $\mathrm{ZnO}$ Nanoparticles," Appled Physics Letters, Vol. 88, No. 25, 2006, Article ID: 252502.

[21] O. D. Jayakumar, I. K. Gopalakrishnan, C. Sudakar, R. M. Kadam and S. K. Kulshreshtha, "Magnetization and Structural Studies of Mn Doped ZnO Nanoparticles: Prepared by Reverse Micelle Method," Journal of Crystal Growth, Vol. 300, No. 2, 2007, pp. 358-363. doi:10.1016/j.jcrysgro.2006.12.030

[22] H. L. Liu, J. H. Yang, Y. J. Zhang, Y. X. Wang, M. B. Wei, D. D. Wang, L. Y. Zhao, J. H. Lang and M. Gao, "Ferromagnetism in Cu-Doped ZnO Nanoparticles at Room Temperature," Journal of Materials Science: Materials in Electronics, Vol. 20, No. 7, 2009, pp. 628-631. doi:10.1007/s10854-008-9776-0

[23] N. Tahir, S. T. Hussain, M. Usman, S. K. Hasanain and A. Mumtaz, "Effect of Vanadium Doping on Structural, Magnetic and Optical Properties of ZnO Nanoparticles," Applied Surface Science, Vol. 255, No. 20, 2009, pp. 8506-8510. doi:10.1016/j.apsusc.2009.06.003

[24] L. B. Duan, G. H. Rao, Y. C. Wang, J. Yu and T. Wang, "Magnetization and Raman Scattering Studies of (Co, Mn) Codoped ZnO Nanoparticles," Journal of Applied Physics, Vol. 104, No. 1, 2008, Article ID: 013909. doi:10.1063/1.2952516

[25] O. D. Jayakumar, I. K. Gopalakrishnan and S. K. Kulshreshtha, "The Structural and Magnetization Studies of Co-Doped ZnO Co-Doped with Cu: Synthesized by CoPrecipitation Method," Journal of Materials Chemistry, Vol. 15, 2005, pp. 3514-3518. doi:10.1039/b507201h

[26] H. W. Zhang, Z. R. Wei, Z. Q. Li and G. Y. Dong, "Room-Temperature Ferromagnetism in Fe-Doped, Feand $\mathrm{Cu}$-Codoped $\mathrm{ZnO}$ Diluted Magnetic Semiconductor," Materials Letters, Vol. 61, No. 17, 2007, pp. 3605-3607. doi:10.1016/j.matlet.2006.11.139

[27] H. Liu, J. Yang, Z. Hua, Y. Liu, L. Yang, Y. Zhang and J. Cao, "Cu-Doping Effect on Structure and Magnetic Properties of Fe-Doped ZnO Powders," Materials Chemistry and Physics, Vol. 125, No. 3, 2011, pp. 656-659. doi:10.1016/j.matchemphys.2010.10.002

[28] S. J. Han, J. W. Song, C. H. Yang, S. H. Park, J. H. Parket and Y. H. Jeong, "A Key to Room-Temperature Ferromagnetism in Fe Doped $\mathrm{ZnO}: \mathrm{Cu}$," Applied Physics Letters, Vol. 81, No. 22, 2002, p. 4212. doi:10.1063/1.1525885

[29] J. Shim, T. Hwang, J. Park, S. J. Han and Y. Jeong, "Origin of Ferromagnetism in Fe- and Cu-Codoped ZnO," Applied Physics Letters, Vol. 86, No. 8, 2005, Article ID: 082503. doi:10.1063/1.1868872

[30] B. Hapke, "Theory of Reflectance and Emittance Spectroscopy," Cambridge University Press, Cambridge, 1993. doi:10.1017/CBO9780511524998

[31] R. Saleh, S. P. Prakoso and A. Fishli, "The Influence of Fe Doping on the Structural, Magnetic and Optical Properties of Nanocrystalline ZnO Particles," Journal of Magnetism and Magnetic Materials, Vol. 324, No. 5, 2012, pp.
665-670. doi:10.1016/j.jmmm.2011.07.059

[32] M. Mukhtar, L. Munisa and R. Saleh, "Co-Precipitation Synthesis and Characterization of Nanocrystalline Zinc Oxide Particles Doped with $\mathrm{Cu}^{2+}$ Ions," Materials Sciences and Applications, Vol. 3, No. 8, 2012, pp. 543-551. doi:10.4236/msa.2012.38077

[33] R. Saleh, N. F. Djaja and S. P. Prakoso, "The Correlation between Magnetic and Structural Properties of Nanocrystalline Transition Metal-Doped ZnO Particles Prepared by the Co-Precipitation Method," Journal of Alloys and Compounds, Vol. 546, 2013, pp. 48-56. doi:10.1016/j.jallcom.2012.08.056

[34] S. P. Prakoso and R. Saleh, "Synthesis and Spectroscopic Characterization of Undoped Nanocrytalline ZnO Particles Prepared by Co-Precipitation," Materials Sciences and Applications, Vol. 3, No. 8, 2012, pp. 530-537. doi:10.4236/msa.2012.38075

[35] G. K. Williamson and W. H. Hall, "X-Ray Line Broadening from Filled Aluminium and Wolfram," Acta Metallurgica, Vol. 1, No. 1, 1953, pp. 22-31. doi:10.1016/0001-6160(53)90006-6

[36] K. Srinivas, S. M. Rao and P. V. Reddy, "Preparation and Properties of $\mathrm{Zn}_{0.9} \mathrm{Ni}_{0.1} \mathrm{O}$ Diluted Magnetic Semiconductor Nanoparticles," Journal of Nanoparticle Research, Vol. 13, No. 2, 2011, pp. 817-837. doi:10.1007/s11051-010-0084-2

[37] C. B. Azzoni, A. Paleari, V. Massarotti and D. Capsoni, "Electron Paramagnetic Resonance Response and Magnetic Interactions in Ordered Solid Solutions of Lithium Nickel Oxides," Journal of Physics: Condensed Matter, Vol. 8, No. 39, 1996, p. 7339. doi:10.1088/0953-8984/8/39/010

[38] E. Zhecheva, R. Stoyanova, R. Alcántara, P. Lavela and J.-L. Tirado, "Cation Order/Disorder in Lithium Transition-Metal Oxides as Insertion Electrodes for LithiumIon Batteries," Pure and Applied Chemistry, Vol. 74, No. 10, 2002, pp. 1885-1894. doi:10.1351/pac200274101885

[39] L. He, X.-X. Wu, H.-G. Liu and W.-C. Zheng, "Theoretical Calculation of EPR g Factors for $\mathrm{Ni}^{3+}$ Ion at the Interstitial Site of $\mathrm{SnO}_{2}$ Crystal," Spectrochimica Acta Part A, Vol. 68, No. 3, 2007, pp. 891-893.

doi:10.1016/j.saa.2006.12.075

[40] S.-Y. Wu, X.-Y. Gao, J.-Z. Lin, Q. Fu and G.-D. Lu, "Studies on the Local Structures of the Substitutional and Interstitial $\mathrm{Ni}^{3+}$ Centers in Rutile," Chemical Physics, Vol. 328, No. 1-3, 2006, pp. 26-32. doi:10.1016/j.chemphys.2006.06.004

[41] R. Elilarassi and G. Chandrasekaran, "Structural, Optical, and Magnetic Characterization of Cu-Doped $\mathrm{ZnO}$ Nanoparticles Synthesized Using Solid State Reaction Method," Journalo of Materials Science: Materials in Electronics, Vol. 21, No. 11, 2010, pp. 1168-1173. doi:10.1007/s10854-009-0041-y

[42] X. L. Li, X. H. Xu, Z. Y. Quan, J. F. Guo, H. S. Wu and G. A. Gehring, "Role of Donor Defects in Enhacing Ferromagnetism of Cu-Doped ZnO Films," Journal of Applied Physics, Vol. 105, No. 10, 2009, Article ID: 103914. doi:10.1063/1.3130104 
[43] A. J. Reddy, M. K. Kokila, H. Nagabhushana, R. P. S. Chakradhard, C. Shivakumara, J. L. Rao and B. M. Nagabhushana, "Structural, Optical and EPR Studies on ZnO:Cu Nanopowders Prepared via Low Temperature Solution Combustion Synthesis," Journal of Alloys and Compounds, Vol. 509, No. 17, 2011, pp. 5349-5355. doi:10.1016/j.jallcom.2011.02.043

[44] N. Y. Garces, L. Wang, L. Bai, N. C. Giles, L. E. Halliburton and G. Cantwell, "Role of Copper in the Green Luminescence from ZnO Crystals," Applied Physics Letters, Vol. 81, No. 4, 2002, p. 622. doi:10.1063/1.1494125

[45] D. M. Hoffmann, A. Hofstaetter, F. Leiter, H. Zhou, F. Henecker and B. K. Meyer, "Hydrogen: A Relevant Shallow Donor in Zinc Oxide," Physical Review Letters, Vol. 88, No. 4, 2002, Article ID: 045504. doi:10.1103/PhysRevLett.88.045504

[46] K. M. Sancier, "ESR Investigation of Photodamage to Zinc Oxide Powders," Surface Science, Vol. 21, No. 1, 1970, pp. 1-11. doi:10.1016/0039-6028(70)90059-2

[47] M. Schulz, "ESR Experiments on Ga Donors in $\mathrm{ZnO}$ Crystals," Physica Status Solidi, Vol. 27, No. 1, 1975, pp. K5-K8. doi:10.1002/pssa.2210270140

[48] P. H. Kasai, "Electron Spin Resonance Studies of Donors and Acceptors in ZnO," Physical Review, Vol. 130, No. 3, 1963, pp. 989-995. doi:10.1103/PhysRev.130.989

[49] A. Hausmann and B. Schallenberger, "Interstitial Oxygen in Zinc Oxide Single Crystals," Zeitschrift fur Physik, Vol. 31, No. 3, 1978, pp. 269-273.

[50] V. Ischenko, S. Polarz, D. Grote, V. Stavarache, K. Fink and M. Driess, "Zinc Oxide Nanoparticles with Defects," Advanced Functional Materials, Vol. 15, No. 12, 2003, pp. 1945-1954. doi:10.1002/adfm.200500087

[51] N. G. Kakazev, T. V. Sreckovic and M. M. Ristic, "Electronic Paramagnetic Resonance Investigation of The Evolution of Defects in Zinc Oxide during Tribophysical Activation," Journal of Materials Science, Vol. 32, No. 7, 2007, pp. 4619-4622. doi:10.1023/A:1018689721667

[52] L. S. Vlasenko, "Magnetic Resonance Studies of Intrinsic Defects in ZnO:Oxygen Vacancy," Applied Magnetic Resonance, Vol. 39, No. 1-2, 2010, pp. 103-111. doi:10.1007/s00723-010-0140-1

[53] M. M. Selim and I. H. Abd El-Maksoud, "Spectroscopic and Catalytic Characterization of Ni Nano-Size Catalyst for Edible Oil Hydrogenation," Microporous and Mesoporous Materials, Vol. 85, No. 3, 2005, pp. 273-278. doi:10.1016/j.micromeso.2005.06.027

[54] P. Thakur, V. Bisogni, J. C. Cezar, N. B. Brookes, G. Ghiringhelli, S. Gautam, K. H. Chae, M. Subramanian, R. Jayavel and K. Asokan, "Electronic Structure of $\mathrm{Cu}-$ Doped ZnO Thin Films by X-Ray Absorption, Magnetic Circular Dichroism, and Resonant Inelastic X-Ray Scattering," Journal of Applied Physics, Vol. 107, No. 10, 2011, Article ID: 103915.

[55] M. Wei, N. Braddon, D. Zhi, P. A. Midgley, S. K. Chen, M. G. Blamire and J. L. MacManus-Driscoll, "Room Temperature Ferromagnetism in Bulk Mn-Doped $\mathrm{Cu}_{2} \mathrm{O}$," Applied Physics Letters, Vol. 86, No. 7, 2005, Article ID:
072514. doi:10.1063/1.1869547

[56] M. S. Seehra, P. Dutta, V. Singh, Y. Zhang and I. Wender, "Evidence for Room Temperature Ferromagnetism in $\mathrm{Cu}_{\mathrm{x}} \mathrm{Zn}_{1-\mathrm{x}} \mathrm{O}$ from Magnetic Studies in $\mathrm{Cu}_{\mathrm{x}} \mathrm{Zn}_{1-\mathrm{x}} \mathrm{O} / \mathrm{CuO}$ composite," Journal of Applied Physics, Vol. 101, No. 9, 2007, Article ID: 09H107.

[57] D. Wang, Z. Q. Chen, D. D. Wang, J. Cong, C. Y. Cao, Z. Tang and L. R. Huang, "Effect of Thermal Annealing on the Structure and Magnetism of Fe-Doped ZnO Nanocrystals Synthesized by Solid State Reaction," Journal of Magnetism and Magnetic Materials, Vol. 322, No. 22, 2010, pp. 3642-3647. doi:10.1016/j.jmmm.2010.07.014

[58] D. A. A. Santos and M. A. Macedo, "Study of the Magnetic and Structural Properties of $\mathrm{Mn}-, \mathrm{Fe}-$, and CoDoped ZnO Powder," Physica B, in Press.

[59] F. Lin, D. M. Jiang and X. M. Ma, "The Influence of Annealing on the Magnetism of Fe-Doped ZnO Prepared by Mechanical Alloying," Physics B, Vol. 405, No. 6, 2010, pp. 1466-1469. doi:10.1016/j.physb.2009.12.010

[60] S. Yılmaz, E. McGlynn, E. Bacaksı, J. Cullen and R. K. Chellappan, "Structural, Optical and Magnetic Properties of Ni-Doped $\mathrm{ZnO}$ Micro-Rods Grown by the Spray Pyrolysis Method," Chemical Physics Letters, Vol. 525, 2012, pp. 72-76. doi:10.1016/j.cplett.2012.01.003

[61] M. Jagodic, Z. Jaglicic, A. Jelen, J. B. Lee, Y. M. Kim, H. J. Kim and J. Dolinsek, "Surface Spin Magnetism of Antiferromagnetic $\mathrm{NiO}$ in Nanoparticle and Bulk Morpholgy," Journal of Physics: Condensed Matter, Vol. 21, No. 21, 2009, Article ID: 215302. doi:10.1088/0953-8984/21/21/215302

[62] C. J. Cong, J. H. Hong and K. L. Zhang, "Effect of Atmosphere on the Magnetic Properties of the Co-Doped ZnO Magnetic Semiconductors," Materials Chemistry and Physics, Vol. 113, No. 1, 2009, pp. 435-440. doi:10.1016/j.matchemphys.2008.06.062

[63] Z. Xiong, X.-C. Liu, S.-Y. Zhuo, J.-H. Yang, E.-W. Shi and W.-S. Yan, "Oxygen Enhanced Ferromagnetism in Cr-Doped ZnO Films," Applied Physics Letters, Vol. 99, No. 5, 2011, Article ID: 052513. doi:10.1063/1.3624589

[64] S. Ramachandran, J. Narayan and J. T. Prater, "Effect of Oxygen Annealing on Mn Doped ZnO Diluted Magnetic Semiconductors," Applied Physics Letters, Vol. 88, No. 24, 2006, Article ID: 242503. doi:10.1063/1.2213930

[65] R. Viswanatha, D. Naveh, J. R. Chelikowsky, L. Kronik and D. D. Sarma, "Magnetic Properties of Fe/Cu Codoped ZnO Nanocrystals," Journal of Physical Chemistry Letters, Vol. 3, No. 15, 2012, pp. 2009-2014. doi: $10.1021 / \mathrm{jz} 300741 \mathrm{z}$

[66] X. F. Liu and R. H. Yu, "Mediation of Room Temperature Ferromagnetism in Co-Doped $\mathrm{SnO}_{2}$ Nanocrystalline Films by Structural Defects," Journal of Applied Physics, Vol. 102, No. 8, 2007, Article ID: 083917. doi:10.1063/1.2801375

[67] G. Venkataiah, M. R. S. Huang, H. L. Su, C. P. Liu and J. C. A. Huang, "Microstructure and Magnetic Properties of Ni:ZnO Nanorod/Zn:NiO Nanowall Composite Structures," Journal of Physics Chemistry C, Vol. 114, No. 39, 2010, pp. 16191-16196. doi:10.1021/jp1036553 
[68] M. El-Hilo, A. A. Dakhel and A. Y. Ali-Mohamed, "Room Temperature Ferromagnetism in Nanocrystalline Ni-Doped $\mathrm{ZnO}$ Synthesized Byco-Precipitation," Journal of Mag- netism and Magnetic Materials, Vol. 321, No. 24, 2009 pp. 2279-2283. doi:10.1016/j.jmmm.2009.01.040 